\title{
Landscape dynamics in endangered cork oak woodlands in Southwestern Portugal (1958-2005)
}

\author{
Augusta Costa $\cdot$ Helena Pereira $\cdot$ Manuel Madeira
}

Received: 30 June 2008/Accepted: 15 January 2009/Published online: 17 February 2009

(C) Springer Science+Business Media B.V. 2009

\begin{abstract}
Cork oak landscape dynamics were assessed over a 47-year period (1958-2005) in an endangered region of southwest Portugal using a GIS approach. The area of cork oak woodlands was maintained during this period, but shifts due to land abandonment were evident leading to transformation of cork oak agriculture areas into woodlands and of cork oak woodlands into shrublands (average yearly change rates of 0.6 and $0.1 \%$, respectively). The multi-temporal landscape analyses showed that expansion and regression rates of cork oak forests were similar (15 and 16 ha year ${ }^{-1}$, respectively). The main factor determining oak woodlands expansion and regression was related to land-use changes, but slope, aspect and soil type were also significant factors. The substitution of agriculture lands and oak woodlands by shrublands has a determining role in periods of disturbance and recovery of these Mediterranean ecosystems.
\end{abstract}

A. Costa $(\bowtie) \cdot$ H. Pereira

Centro de Estudos Florestais, Instituto Superior de Agronomia, Universidade Técnica de Lisboa, Tapada da Ajuda, 1349-017 Lisbon, Portugal

e-mail: augustac@isa.utl.pt

\section{Madeira}

Centro de Pedologia, Instituto Superior de Agronomia, Universidade Técnica de Lisboa, Tapada da Ajuda, 1349-017 Lisbon, Portugal
Keywords Quercus suber L. · Cork oak forest dynamics - Montado ecosystem - Landscape analysis

\section{Introduction}

The cork oak (Quercus suber L.) is an important species known by its ability of producing a thick cork layer in the outer bark in a sustainable way during the tree's life i.e., by regenerating it after cork extraction (Pereira and Tomé 2004).

In Portugal, the cork oak is the most economically important oak species in an agroforestry system named "montado", characterized by open tree layer of evergreen oaks, with shrub or annual herbaceous understory (Joffre et al. 1999), as cork is a valuable non-wood forest product (NWFP) used industrially mainly for the production of wine stoppers (Pereira 2007).

The national cork oak area (about 737,000 ha) represents $23 \%$ of the total forest area (DGRF 2007), and has increased at a rate of 2,000 ha year ${ }^{-1}$, from an estimated area of 637,000 ha in 1956 (Nogueira 1990). The area increase rate was higher since 1980 , at nearly 3,500 ha year ${ }^{-1}$ (DGF 1985, 2001), as a result of the financial support of EU's CAP, through agro-environmental measures (Pinto-Correia and Mascarenhas 1999).

Cork oak is well-adapted to summer drought (David et al. 1992; Oliveira et al. 1992), exhibiting 
morphological and physiological adaptations like deep-reaching root systems and sensitive stomatal regulation (David et al. 2004). Its regional distribution is mostly related to drought severity, hydromorphic site conditions and soil-site-water availability relations (David et al. 2007; Costa et al. 2008). It has been stated that cork oak density in "montado" depends on mean annual rainfall (Gouveia and Freitas 2008), similarly to what was reported for the agroforestry system "dehesa" where holm oak $(Q$. ilex L.) and cork oak (Q. suber L.) are the dominant Mediterranean evergreen oaks (Joffre et al. 1999).

The ecological biodiversity linked to cork oak management factors and land-use changes, due to desertification processes, have shaped the "montado" ecosystem into a sustainable, dynamic heterogeneous landscape with an increasing mosaic contrast (Barbero et al. 1990; Pereira and Fonseca 2003; PintoCorreia and Vos 2004). However, the increasing visible damages in cork oak woodlands, noticed since mid-1980 across the Mediterranean region, including southwestern Portugal (Brasier and Scott 1994), paralleling to the general oak decline in Europe (Oszako 2000) and in North America (Oak et al. 1996; Shifley et al. 2006), have led to concerns on their overall sustainability (David et al. 1992).

The occurrence of tree decline symptoms such as crown thinning, discoloration of leaves, crown reduction and tree complete dehydration, in single or grouped trees, or in small areas within the stands, stimulated efforts to determine the influence of single or combined abiotic (e.g., recurrent drought periods) and biotic (e.g., pathogenic fungi) factors on the cork oak decline. Some associations between stand-site attributes and oak decline were detected, i.e., progressive crown dieback of cork oaks has been associated with xeric site conditions of shallow soils or hydromorphic soil conditions (David et al. 1992; Diniz 1994; Sousa et al. 2000), defoliation, insect attacks, pathogenic fungi (Wargo 1996; Brasier 1996; Moniz et al. 1996) and inappropriate silvicultural management (Cadima et al. 1995).

One of the most important characteristics of these ecosystems is the high spatial and temporal variation, with patch patterns representing direct responses to varying habitat conditions and cycles of disturbance and recovery. However, this subject has been neglected in research. So far, information on landscape dynamics of cork oak woodlands was only reported by Carvalho et al. (1992) who estimated changes in the tree canopy cover in an endangered cork oak "montado" area in southwestern Portugal, over the period 1958-1987. In Spain, similar studies were reported by Cano et al. (2003) for an endangered cork oak "dehesa" area in Cádiz for the period 1977-2000, and by Plieninger (2006) for a holm oak "dehesa" area in Cáceres over a 42-year period (1956-1998).

The aim of this paper is to study the spatialtemporal evolution of a cork oak "montado" at a landscape-level for the period 1958-2005. The objectives are to evaluate the shifting patterns and rates in relation to land-use and to landscape physic attributes and to describe and predict trends of change using logistic regression models in order to better understand the ecosystem functioning and processes.

\section{Materials and methods}

\section{Study area}

The study area comprised the county of S. Bartolomeu da Serra (Santiago do Cacém) in south-western Portugal, located at $38^{\circ} 04^{\prime} \mathrm{N}-08^{\circ} 40^{\prime} \mathrm{W}$ and $37^{\circ} 56^{\prime} \mathrm{N}-$ $08^{\circ} 34^{\prime} \mathrm{W}$, with a total area of 6,224 ha. This county is mostly rural, dominated by a large area of cork oak woodlands representative of the multifunctional agroforestry systems of "montado".

The climate is of Mediterranean type with ocean influence, with the highest temperatures during summer when rainfall is lowest. Relative air humidity ranges between 77 and $84 \%$. The mean annual rainfall is $676 \mathrm{~mm}$, mainly concentrated in late autumn, winter and early spring. In the last 50-years (1950-2000) the annual precipitation varied between consecutive years and periods with enlarged belowmean values were noticed since 1970 (Fig. 1), but the precipitation in the October-February period in two consecutive overlapping 30-year periods only slightly decreased from $485 \mathrm{~mm}$ (1961-1990) to $464 \mathrm{~mm}$ (1971-2000). The mean annual temperature showed a small increase [15.6 and $15.8^{\circ} \mathrm{C}$, respectively (INAG 2008) http://snirh.pt/snirh.php?main_id=2\&item=1.1 \&objlink=\&objrede=HIDRO], following the trend reported by Miranda et al. (2002) for southern Portugal. 


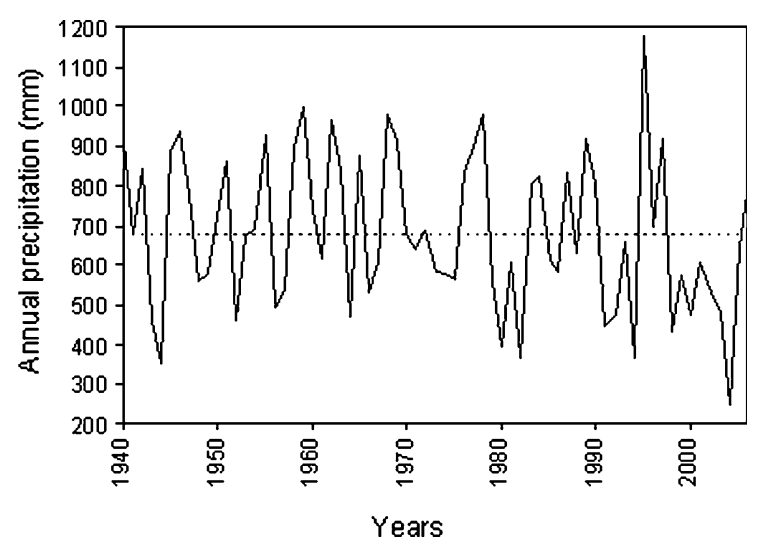

Fig. 1 Annual precipitation for the period 1940-2006 in the S. Bartolomeu da Serra region

In the study area two geomorphologic units were identified: one flat or gentle undulating area located on the central eastern part of the county with an elevation from 120 to $180 \mathrm{~m}$ a.s.l. dominated by slopes up to $15 \%$; and another steep undulating area with rounded to flattened hilltops and with smooth hillsides at an elevation from 85 to $263 \mathrm{~m}$ a.s.l., mostly with slopes between 5 and $35 \%$, with higher slopes $(>35 \%)$ in small areas near the main water lines.

In both geomorphologic units, geological formations are mostly related to schists (grauwakes, silstones, carbonaceous schists) with vertical stratification. Sedimentary formations of the PlioPlistocenic (sandstones with variable clay content and sands) occur at a low extent and overlay the schist formations in rounded flattened hilltops of the steep undulating geomorphologic unit (Inverno et al. 1993).
On schist formations, according to the Portugal Soil Map (SROA 1962), soils are mostly Haplic Leptosols (sensu WRB 2006) with a soil depth up to compact rock less than $25 \mathrm{~cm}$, dominant in the steep undulating area, and Epileptic Luvisols with compacted rock between 25 and $50 \mathrm{~cm}$ depth, dominant in the flat or gentle undulating areas. These soils show silty clay to silty clay loam texture, $\mathrm{pH}\left(\mathrm{H}_{2} \mathrm{O}\right)$ of 5.9 , organic $\mathrm{C}$ concentration of $22.3 \mathrm{~g} \mathrm{~kg}^{-1}$ and concentrations of extractable $\mathrm{K}$ and $\mathrm{P}$ of 151 and $2.3 \mathrm{mg} \mathrm{kg}^{-1}$, respectively (Table 1). Haplic Leptosols and Epileptic Luvisols developed on schists represent, respectively, 73 and $23 \%$ of the study area. On sandstones (mostly clay sandstones) soils are Haplic Leptosols (2\%) and show similar characteristics to those developed on schists. Soils developed on sands are mostly Haplic Arenosols (about 2\%) and show coarser texture (sandy to loam sandy), and lower concentration of organic $\mathrm{C}$ and of extractable $\mathrm{K}$ than the others (Table 1). Small areas of Fluvisols (less than 1\%) also occur in the study area.

The study area is within a biogeographical unit characterized by the dominant species of the MyrtoQuercetum suberis association underlying shrublands of the association Genisto hirsutae-Cistetum ladaniferi (Costa et al. 1998). Since 1975 only four small fires occurred in 1991, 2002 and 2003, in a total of 85 ha of fired area, mainly located in shrublands (Pereira and Santos 2003).

\section{Methodology}

The cartographic analysis of the landscape and cork oak area of S. Bartolomeu da Serra was carried out for two dates: 1958, when the first aerial photographs

Table 1 Average of selected chemical characteristics of the $0-15 \mathrm{~cm}$ top soil layer (LPx-Haplic Leptosols on schists; LVx-Epileptic Luvisols; LPst-Haplic Leptosols on sandstones; AR-Haplic Arenosols)

\begin{tabular}{lllllll}
\hline Soil units & $\begin{array}{l}\mathrm{pH} \\
\left(\mathrm{H}_{2} \mathrm{O}\right)\end{array}$ & $\begin{array}{l}\text { Org C } \\
\left(\mathrm{g} \mathrm{kg}^{-1}\right)^{\mathrm{a}}\end{array}$ & $\begin{array}{l}\text { Exch Ca } \\
\left(\mathrm{cmol}_{\mathrm{c}} \mathrm{kg}^{-1}\right)^{\mathrm{b}}\end{array}$ & $\begin{array}{l}\text { Exch Mg } \\
\left(\mathrm{cmol}_{\mathrm{c}} \mathrm{kg}^{-1}\right)^{\mathrm{b}}\end{array}$ & $\begin{array}{l}\text { Ext P } \\
\left(\mathrm{mg} \mathrm{kg}^{-1}\right)^{\mathrm{c}}\end{array}$ \\
\hline LPx; LVx & 5.9 & 22.3 & 2.90 & 2.06 & 2.29 & $\begin{array}{l}\text { Ext K } \\
\left(\mathrm{mg} \mathrm{kg}^{-1}\right)^{\mathrm{c}}\end{array}$ \\
LPst & 5.8 & 21.1 & 2.21 & 2.03 & 0.51 & 51 \\
AR & 5.7 & 10.2 & 0.56 & 0.14 & 2.74 & 18 \\
\hline
\end{tabular}

\footnotetext{
${ }^{a}$ By the wet oxidation method

b Extracted by ammonium acetate at $\mathrm{pH} 7$

c Extracted by the Egnér-Riehm method
} 
were taken, and 2005. The aerial photographs (greyscale) taken in 1958, (Portuguese Air Force) (scale $1: 15,000)$ were scanned at high resolution (600 dpi), ortho-rectified using ERDAS IMAGINE with a positional accuracy lower than $5 \mathrm{~m}$, and images were projected onto the National Coordinate System (Gauss Projection, datum 73 Lisbon). For 2005, the ortho-rectified aerial photographs in natural color from the Portuguese Geographic Institute were used and projected onto the National Coordinate System (Gauss Projection, datum 73 Lisbon).

A spatial database was constructed based on: (1) the geo-referentiated digital cover of the Portuguese Soil Map at 1:25,000 (SROA 1962). The Reference Soil Groups (RSG) (WRB 2006), adapted from the Portuguese Soil Classification (Cardoso 1965), were considered in the study in order to use a standard denomination for soils; and (2) the digital aspect and slope maps with 10-m spatial resolution based on the digital terrain model (DTM) derived from a 1: 25,000 topographic map from the Portuguese Army Geographic Institute. Five aspect classes were considered: none (with no dominant aspect), North $\left(0-45^{\circ}\right.$ and $\left.315-360^{\circ}\right)$, East $\left(45-135^{\circ}\right)$, South $\left(135-225^{\circ}\right)$ and West $\left(225-315^{\circ}\right)$, representing, respectively 40,15 , 13,17 and $16 \%$ of the study area. Four slope classes were considered: $<5,5-15,15-35$ and $>35 \%$, representing, respectively $44,17,26$ and $13 \%$ of the study area.

The landscape composition classes considered in the photo-interpretation were Woodlands, Shrublands, Agriculture lands, Social areas and Water areas. In general, the woodlands were defined by a tree density over 20 trees $\mathrm{ha}^{-1}$; agriculture lands were rainfed areas with herbaceous (pastures and fields) and shrublands were lower intensity land use areas with shrub encroachment, i.e., with an increase of woody plant cover, dominated by encroaching shrub species.

The minimum mapping unit area was 0.5 ha patch $^{-1}$ for all classes except for water areas that could be smaller and for linear formations (e.g., houses or roads) where the minimum mapping unit was $20 \mathrm{~m}$ width and smaller patches were merged by neighbour patches. The landscape composition was quantified by the sum of areas covered by each class.

The cork oak area was distributed in three distinct heterogeneous landscapes strata or agroforestry systems: (1) Cork oak woodlands (more than 20 trees $\mathrm{ha}^{-1}$ ), in areas with underlying diverse sclerophyllous shrub communities (shrub encroachment) or in areas with the understory dominated by cultivated annual/biannual herbaceous in pastures (herbaceous) alternating with fallow years (shrubs), traditionally used for extensive livestock raising; (2) Rainfed agriculture lands with cork oak trees (more than 5 trees $\mathrm{ha}^{-1}$ ) with underlying natural grasslands or legumes for fodder, occasionally cultivated for cereal crops; (3) Shrublands, in shrub encroachment areas with cork oak trees (more than 5 trees ha ${ }^{-1}$ ) used traditionally for hunting.

The cork oak area in 2005 was classified by tree crown cover as the canopy area percentage of total area in three classes (clear $<25 \%$; open $25-50 \%$; dense $>50 \%$ ) and characterized in relation to mortality in three classes of number of dead trees per ha: with no mortality ( 0 or 1 dead trees $\left.\mathrm{ha}^{-1}\right)$; with normal mortality (between 1 and 5 dead trees ha ${ }^{-1}$ ); and with mortality (more than 5 dead trees ha ${ }^{-1}$ ). In 1958 given the difficulties to distinguish healthy and dead trees in a black and white film, the total cork oak area was not classified in relation to mortality.

The methodology comprised four main stages: (1) Landscape trends - comparative analysis of the digital aerial photos of 1958 and 2005 to estimate trends and rates of changes in landscape composition and structure; (2) Cork oak area trends-comparative analysis of the digital aerial photos of 1958 and 2005 to estimate trends and rates of changes in the cork oak area composition and structure, including canopy cover; (3) Determination of areas of cork oak forest expansion and regression with the corresponding characterization of landscape features and; (4) Prediction of shifting areas for cork oak at landscape level based on logistic regression model with GIS variables.

Cork oak forest was defined as cork oak woodlands with medium or high canopy cover $(>25 \%)$, with no mortality or with normal mortality in 2005, including the reforestation areas with cork oak since they will have a canopy cover $>50 \%$. The area of cork oak forest expansion was quantified as the sum of patches classified in 2005 as cork oak forests that in 1958 were agriculture lands, shrublands or cork oak woodlands with low canopy cover $(<25 \%)$.

A cork oak forest expansion index (EI) was calculated for each cork oak class, strata/landscape/ stand features (e.g., woodlands, slope or understory classes) or combination of classes based on the general formula (1) where $a_{k i}$ is the area of the patch $i$ 
coded as cork oak forest expansion patch of the class $k, n$ is the number of cork oak forest expansion patches of the class $k$ and $A_{k}$ is the 1958 cork oak area, agriculture lands or shrublands that originated the 2005s cork oak area, of the class $k$.

$\operatorname{Int}\left(\frac{\sum_{i=1}^{n} a_{k i}}{A_{k}} \times 10\right)$

Cork oak forest regression was considered to occur when the cork oak forest decreased their canopy cover to $<25 \%$ or were shifted to the other vegetation land uses of agriculture or shrublands. The area of cork oak forest regression was quantified as the sum of patches that were classified in 1958 as cork oak forest that in 2005 were low canopy cover cork oak woodlands $(<25 \%)$, agriculture lands or shrublands.

A cork oak forest regression index (RI) was calculated based on the formula (1) where $a_{k i}$ is the area of the patch $i$ coded as cork oak forest regression patch of the class $k, n$ is the number of cork oak forest regression patches of the class $k$ and $A_{k}$ is the 1958 cork oak area that originated the 2005 cork oak area, agriculture lands and shrublands of the class $k$.

Cork oak mortality area in 2005 was quantified as the sum of cork oak patches area coded as "with mortality". A cork oak mortality index (MI) was calculated for each cork oak class, strata/landscape/ stand features (e.g., woodlands, slope or understory classes) or combination of classes based on the formula (1) where $a_{k i}$ is the area of the patch $i$ with mortality of the class $k, n$ is the number of patches with mortality of the class $k$ and $A_{k}$ is the total patch area of the class $k$. The correlation of cork oak area shifting with spatial patterns was based on the comparison of landscape attributes in random selected patches with more than 0.5 ha of cork oak forest "expansion" or "regression" areas confirmed with field work. A univariate logistic regression analysis (SPSS 2008) on the GIS-data was made in order to characterize the relative importance of categorical variables soil type, aspect, slope, and vegetation classes. A multivariate analysis using forward stepwise logistic regression (SPSS 2008) modeled the above GIS-data.

\section{Results}

Landscape changes and dynamics

The landscape composition of S. Bartolomeu da Serra for 1958 and 2005 is summarized in Table 2 regarding the five land use groups: agriculture lands, woodlands, shrublands, social areas and water surfaces. Their spatial distribution is shown in Fig. 2.

The dominant land use was woodlands (69 and $68 \%$ of the total area in 2005 and 1958, respectively), but agriculture was also important (22 and 30\% in 2005 and 1958, respectively). The main land use characteristics of S. Bartolomeu da Serra were maintained in the period 1958-2005, although some differences in change trends were observed. For instance, agriculture lands had a decrease of $0.6 \%$ year $^{-1}$ (from 1,882 to 1,345 ha) and woodlands maintained their area (4,230 and 4,269 ha) (Table 2).

In the 1958-2005 period, 3,660 ha (87\%) of the woodlands area were maintained while 272 ha were turned to agriculture and 271 ha into shrublands. This decrease (12 ha year ${ }^{-1}$ ) was compensated by 562 ha of agriculture lands which changed to woodlands (Table 2). On the other hand, agriculture lands had a decrease of about 11 ha year ${ }^{-1}$ as a result of land use shift mainly to woodlands and shrublands that were only partially compensated by the gain of 272 ha from woodlands (6 ha year $\left.{ }^{-1}\right)$.

Shrublands were the land use class that mostly increased in proportion from 1958 to 2005 , when they represented 1 and $8 \%$ of the total area, respectively, and appeared as small areas with shrub encroachment
Table 2 S. Bartolomeu da Serra landscape composition and transition matrix for the period 1958-2005 based on five main land use classes: woodlands, agriculture lands, shrublands, social and water areas

Unit hectares

\begin{tabular}{lccccc}
\hline 1958 & 2005 & & & & \\
\cline { 2 - 6 } & Agriculture & Woodlands & Shrublands & Urban areas & Water \\
\hline Agriculture & 1,068 & 562 & 181 & 64 & 6 \\
Woodlands & 272 & 3,660 & 271 & 21 & 7 \\
Shrublands & 4 & 45 & 25 & 0 & 0 \\
Urban areas & 1 & 1 & 1 & 33 & 0 \\
Water & 0 & 0 & 0 & 0 & 0 \\
\hline
\end{tabular}



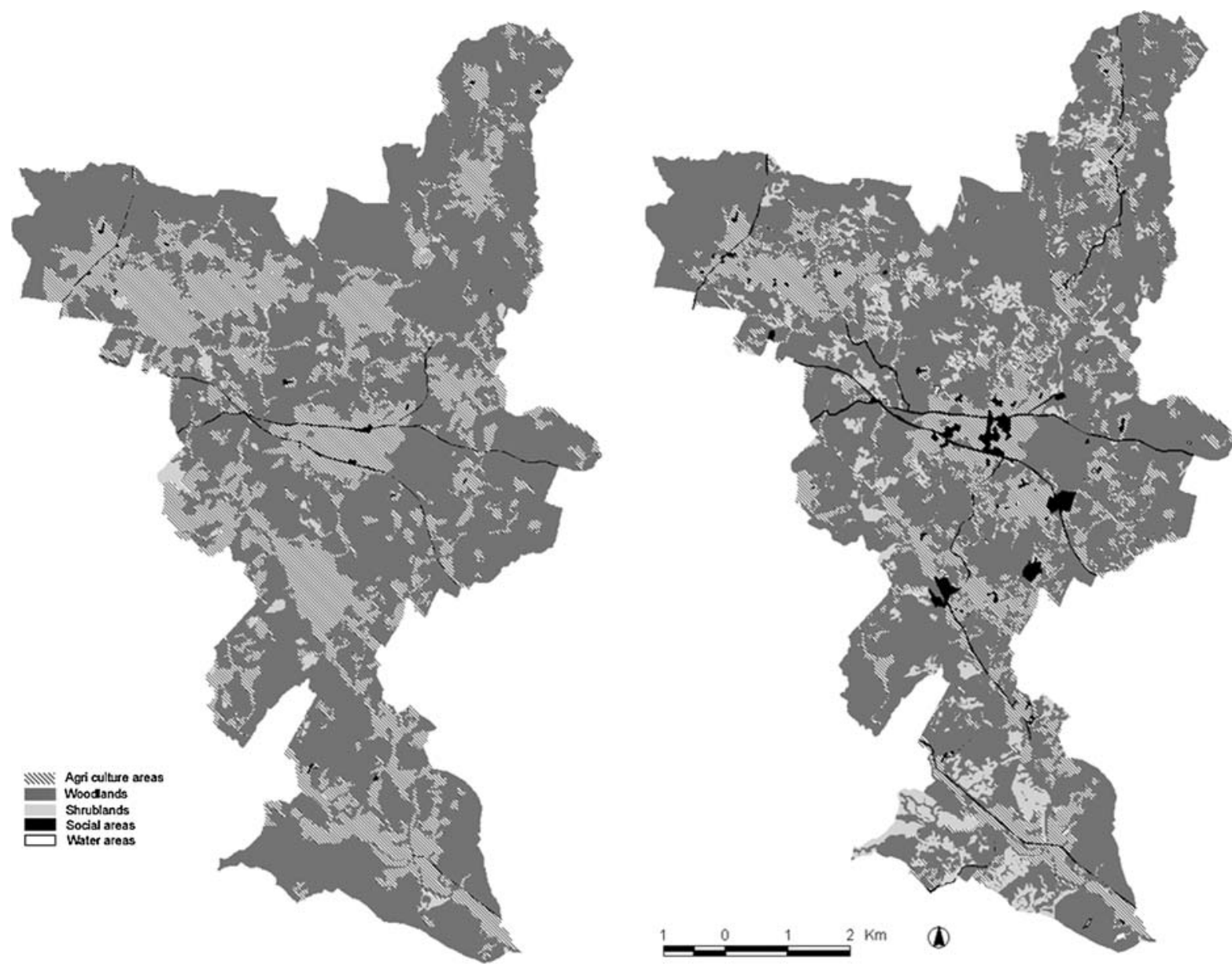

Fig. 2 S. Bartolomeu da Serra land cover based on five main land use classes: woodlands, agriculture lands, shrublands, social and water areas: land cover in 1958 (left); land cover in 2005 (right)

following land abandonment (Fig. 2). The increase of shrublands of $11 \%$ year $^{-1}$ derived mostly from invasion of woodlands (271 ha) and of agriculture lands (181 ha) (Table 2).

The social areas increased in the considered period, mainly because of the urban development of the village of S. Bartolomeu da Serra as well as of the establishment of three new pig production units and of road construction. The increase of water surfaces was mostly due to construction of small dams to provide water for cattle (Fig. 2).

Cork oak landscape changes and dynamics

The cork oak area totalled 4,875 ha in 1958 and 5,023 ha in 2005. Its distribution between the three agroforestry systems, woodlands, agriculture lands and shrublands showed woodlands as dominant with 86 and $84 \%$ of the total cork oak area in 1958 and 2005, respectively. Agriculture lands comprised 13\% of the total cork oak area in 1958 and only $7 \%$ in 2005, whereas shrublands had $1 \%$ in 1958 and $8 \%$ in 2005 (Table 3).

The transition matrix for the cork oak area showed a very small increase ( 0.8 ha year $\left.{ }^{-1}\right)$ in woodlands, since loss rates were balanced with gain rates. In contrast, the cork oak area in agriculture lands had an overall decrease of 6 ha year ${ }^{-1}$ (from 631 to 369 ha) in result of the yearly loss of 11 ha year $^{-1}$, derived of land use shift mainly to woodlands, that was only partially overcome by a yearly gain of 6 ha year ${ }^{-1}$. Shrublands increased at a rate of 9 ha year $^{-1}$ to which contributed mainly a land use shift from woodlands of 6 ha year ${ }^{-1}$ (Table 3). 
Table 3 Transition matrix of the cork oak area in S. Bartolomeu da Serra for the period 1958-2005 based on the three cork oak area strata: woodlands (classified by understory), agriculture lands and shrublands

\begin{tabular}{|c|c|c|c|c|c|c|}
\hline \multirow[t]{4}{*}{1958} & \multicolumn{6}{|l|}{2005} \\
\hline & \multicolumn{5}{|c|}{ Cork oak area } & \multirow[t]{3}{*}{ Non cork oak area } \\
\hline & \multicolumn{3}{|l|}{ Woodlands } & \multirow[t]{2}{*}{ Shrublands } & \multirow[t]{2}{*}{ Agricultural lands } & \\
\hline & Herbaceous & Shrub & Shrub encroachment & & & \\
\hline Cork oak area & 2,479 & 830 & 686 & 355 & 280 & 246 \\
\hline Woodlands & 2,243 & 768 & 620 & 251 & 179 & 139 \\
\hline Herbaceous & 2,046 & 456 & 426 & 185 & 170 & 127 \\
\hline Shrub & 137 & 283 & 131 & 24 & 7 & 6 \\
\hline Shrub encroachment & 60 & 28 & 64 & 42 & 2 & 5 \\
\hline Shrublands & 14 & 7 & 3 & 9 & 1 & 10 \\
\hline Agricultural lands & 221 & 56 & 63 & 94 & 100 & 97 \\
\hline Non cork oak area & 136 & 61 & 44 & 62 & 89 & 956 \\
\hline
\end{tabular}

Unit hectares

In relation to understory of cork oak woodlands, the transition matrix showed that the herbaceous understory was dominant in 1958 and 2005. Nevertheless some differences were observed: shrub encroachment increased from 5 to $17 \%$ and shrubs increased from 14 to $21 \%$ whereas the herbaceous understory decreased from 81 to $62 \%$ of the cork oak woodlands area.

Shrub encroachment increased at an average rate of 10 ha year ${ }^{-1}$, to which contributed mainly the shift from the herbaceous understory of 9 ha year ${ }^{-1}$. In cork oak woodlands with herbaceous understory the loss rate was almost 2.5 times more than the gain rate (29 and 12 ha year ${ }^{-1}$, respectively).

\section{Landscape fragmentation}

The landscape structure showed an increase of mosaic fragmentation from 1958 to 2005 (Table 4). This increase of fragmentation occurred mainly in woodlands where the mean patch size decreased from 4.5 to 2.3 ha and in agriculture lands from 6.4 to 4.0 ha. Shrublands had the smallest mean patch area (1.7 ha) and maintained it in this period. When considering only the cork oak area, the same type of mosaic fragmentation occurred between 1958 and 2005 in woodlands and agriculture lands: mean patch size decreased from 4.6 to $2.3 \mathrm{ha}$, and from 3.5 to 1.9 ha, respectively. The mean patch size in shrublands increased from 1.7 to 2.2 ha.
Table 4 Transition matrix of the cork oak area in S. Bartolomeu da Serra for the period 1958-2005 based on the three cork oak area agroforestry systems: woodlands, agriculture lands and shrublands

\begin{tabular}{|c|c|c|}
\hline \multirow[t]{2}{*}{ Landscape classes } & \multicolumn{2}{|c|}{ Mean patch area in ha (No. of patches) } \\
\hline & 1958 & 2005 \\
\hline \multicolumn{3}{|l|}{ Total area } \\
\hline Woodlands & $4.5(933)$ & $2.3(1,853)$ \\
\hline Agriculture & $6.4(295)$ & $4.0(336)$ \\
\hline Shrublands & $1.7(45)$ & $1.7(283)$ \\
\hline Social areas & $2.0(18)$ & $2.3(51)$ \\
\hline Water & $0.3(3)$ & $0.4(33)$ \\
\hline \multicolumn{3}{|l|}{ Cork oak area } \\
\hline Woodlands & $4.6(921)$ & $2.3(1,814)$ \\
\hline Agriculture & $3.5(178)$ & $1.9(220)$ \\
\hline Shrublands & $1.7(26)$ & $2.2(165)$ \\
\hline
\end{tabular}

Canopy cover changes and dynamics

The cork oak woodlands were mostly dense stands with about half of the area with a canopy cover superior to $50 \%$ both in 1958 and 2005. In the 19582005 period the dense and clear cork oak woodlands increased at rates of 0.2 and $0.1 \%$ year $^{-1}$, which corresponded to a gain rate of 4 and 1 ha year ${ }^{-1}$, respectively. In contrast, the open cork oak woodlands showed a decrease rate of $0.4 \%$ year $^{-1}$ corresponding to a loss of 4 ha year $^{-1}$ (Fig. 3). 


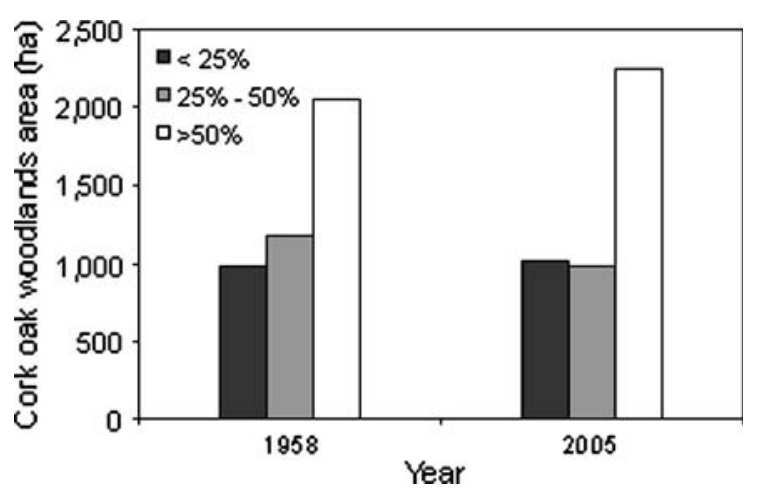

Fig. 3 Changes in S. Bartolomeu da Serra cork oak woodlands area discriminated by canopy cover classes

The increase of dense cork oak woodlands was mainly derived from open woodlands shifting at a rate of 3 ha year ${ }^{-1}$, and the increase of clear cork oak woodlands was mainly related to the shift of agriculture lands and shrublands at a rate of 2 ha year $^{-1}$. In open cork oak woodlands, the area decrease ( 2 ha year ${ }^{-1}$ ) resulted mainly from their shifting to dense woodlands that was not compensated from the gain from clear woodlands shifting.

Cork oak mortality

The cork oak mortality in 2005 totaled 834 ha mainly occurring in woodlands (556 ha, representing $13 \%$ of cork oak woodlands) and in shrublands (211 ha, representing $51 \%$ of cork oak shrublands).

The transition matrix for cork oak mortality area is shown in Table 5. Mortality was maximal in shrublands or agriculture lands especially in those that were previously woodlands with shrub or shrub encroachment understories (MI ranging between 7 and 8). In general, less mortality was found in cork oak areas that were stable in the period, e.g., cork oak woodlands and shrublands had a MI of 1 and agriculture areas a MI of 2 . The shift of woodlands or agriculture lands to shrublands represented an increase in the cork oak mortality occurrence, corresponding to a MI increase from 1 to 6 and from 2 to 5 , respectively.

Cork oak forest dynamics of expansion and regression

According to temporal dynamics of the cork oak landscape the cork oak forest expansion area totaled 726 ha and the cork oak forest regression area totalled 772 ha. The expansion rate of 15 ha year $^{-1}$ was slightly lower than the regression rate (16 ha year $\left.{ }^{-1}\right)$. The spatial distribution of cork oak forest expansion and regression in S. Bartolomeu da Serra shows that they are distributed in all the study area. However, regression is concentrated in the southern part while expansion is more fragmented (Table 4) and located in the northern part (Fig. 4).

Distinct dynamics of expansion and regression of cork oak forests were found for the different landscape features, as shown in Table 6. The woodlands concentrated most of the cork oak forest expansion and regression area, with equal EI and RI indexes $(\mathrm{EI}=1$ and $\mathrm{RI}=1)$. In agriculture lands the cork oak forest expansion occurred in a higher extent than regression while in shrublands was the opposite. Nevertheless, lower incidence of expansion in relation to regression was found in agriculture lands $(\mathrm{EI}=3$ and $\mathrm{RI}=4)$ and equal (and maximal) incidence of cork oak forest expansion and regression was found for shrublands (EI $=5$ and $\mathrm{RI}=5$ ).
Table 5 Transition matrix of the cork oak mortality area (ha) for the period 1958-2005 in

S. Bartolomeu da Serra
Mortality indexes in brackets

\begin{tabular}{lrrr}
\hline 1958 & \multicolumn{2}{l}{2005} & \\
\cline { 2 - 4 } & Woodlands & Shrublands & Agricultural lands \\
\hline Cork oak area & & & \\
Woodlands & $469[1]$ & $146[6]$ & $35[2]$ \\
Herbaceous & $353[1]$ & $99[5]$ & $28[2]$ \\
Shrub & $64[1]$ & $19[8]$ & $6[8]$ \\
$\quad$ Shrub encroachment & $52[3]$ & $27[7]$ & $1[8]$ \\
Shrublands & $2[1]$ & $1[1]$ & $0[3]$ \\
Agriculturelands & $44[1]$ & $43[5]$ & $19[2]$ \\
Non Cork oak area & $41[2]$ & $22[3]$ & $13[1]$ \\
Total & $556[1]$ & $211[5]$ & $67[2]$
\end{tabular}




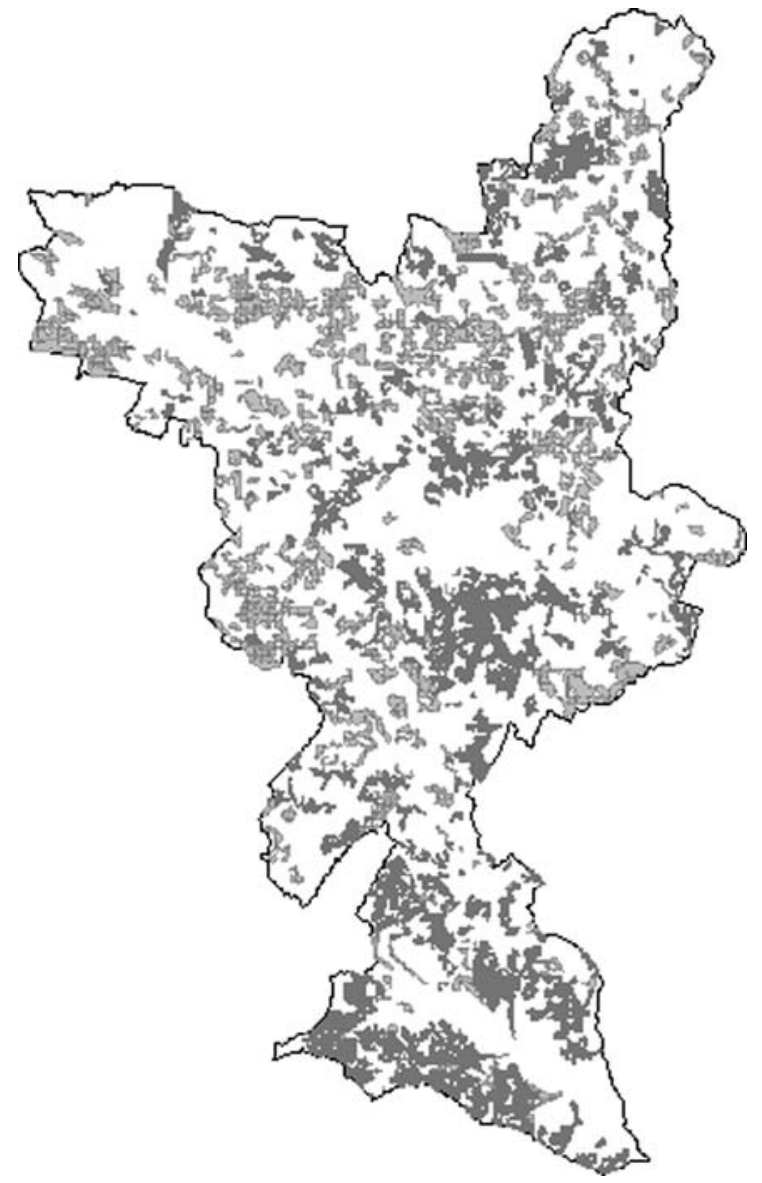

Fig. 4 Cork oak forest expansion area (light grey) and cork oak forest regression area (dark grey) at S. Bartolomeu da Serra for the period 1958-2005

Cork oak forest expansion and regression were mainly located in Leptosols developed on schists: expansion totalled 627 ha $(86 \%$ of total new cork oak forest) and regression totalled 511 ha, representing $66 \%$ of total cork oak regression area $(\mathrm{EI}=2$ and $\mathrm{RI}=1)$. In all the other soils, the cork oak forest regression incidence was higher than the expansion incidence. This was evident in LVx where only 87 ha of cork oak forest expansion $(E I=1)$ were found but 233 ha corresponded to cork oak forest regression $(\mathrm{RI}=2)$. In small areas, in LPst, the EI and RI were maximal $(E I=3$ and $\mathrm{RI}=5)$.

Expansion and regression of cork oak forests occurred in all classes of slope and aspect where EI and RI ranged between 1 and 2. Cork oak forest expansion was noticed in north and east aspect in slopes above $15 \%$ while regression was found in
Table 6 Cork oak forest expansion and regression area (ha) and indexes (EI and RI) for the period 1958-2005 in S. Bartolomeu da Serra in relation to agroforestry systems, slope, aspect and soil type

\begin{tabular}{lcc}
\hline Landscape feature & \multicolumn{2}{c}{ Cork oak forest area (ha) and indexes } \\
\cline { 2 - 3 } & Expansion (EI) & Regression (RI) \\
\hline Agroforestry system & & \\
Agriculture & $288[3]$ & $175[4]$ \\
Woodlands & $409[1]$ & $401[1]$ \\
Shrublands & $29[5]$ & $195[5]$ \\
Soils & & \\
LPx & $627[2]$ & $511[1]$ \\
LVx & $87[1]$ & $233[2]$ \\
LPst & $3[3]$ & $4[5]$ \\
AR & $7[1]$ & $17[2]$ \\
FV & $3[1]$ & $7[2]$ \\
Aspect & & \\
None & $267[1]$ & $331[2]$ \\
North & $148[2]$ & $73[1]$ \\
East & $101[2]$ & $82[1]$ \\
South & $108[1]$ & $163[2]$ \\
west & $101[1]$ & $123[2]$ \\
Slope & & $358[2]$ \\
$<5 \%$ & $280[1]$ & $160[2]$ \\
$5-15 \%$ & & $53]$ \\
$15-35 \%$ & & {$[1]$} \\
$>35 \%$ & & \\
\hline
\end{tabular}

LPx Haplic Leptosols on schists; LVx Epileptic Luvisols; LPst Haplic Leptosols on sandstones; AR Haplic Arenosols; FV Fluvisols

south and no dominant aspect in slopes below $15 \%$ (Table 6).

Predicting shifting cork oak area

The results of univariate logistic regression for the occurrence of cork oak forest expansion and regression with the variables slope, aspect, soil and agroforestry system are summarized in Table 7 . The scores for cork oak forest expansion-no expansion and regression-no regression areas showed that the occurrence of shifting differed with most landscape patterns, although with a very different affinity to the considered variables.

For expansion, the highest odds ratios were found for shrublands and agriculture lands, where cork oak 
Table 7 Logistic regression "odds ratio" for independent variables, agroforestry systems, slope, aspect and soil type (LPx-Haplic Leptosols on schists; LVx-Epileptic Luvisols; LPst-Haplic Leptosols on sandstones; AR-Haplic Arenosols; FV-Fluvisols) for cork oak forest expansion/ no-expansion and regression/no-regression area

\begin{tabular}{|c|c|c|c|c|}
\hline \multirow[b]{2}{*}{ Variables } & \multicolumn{2}{|c|}{$\begin{array}{l}\text { Cork oak expansion } \\
\text { area }(n=1,436)\end{array}$} & \multicolumn{2}{|c|}{$\begin{array}{l}\text { Cork oak regression } \\
\text { area }(n=1,413)\end{array}$} \\
\hline & Odds ratio & Standard error & Odds ratio & Standard error \\
\hline \multicolumn{5}{|c|}{ Agroforestry system } \\
\hline Agriculture & $4.687 * * *$ & 0.180 & $4.730 * * *$ & 0.173 \\
\hline Woodlands & $0.193 * * *$ & 0.178 & $0.134 * * *$ & 0.157 \\
\hline Shrublands & $10.040 * *$ & 0.676 & $7.040 * * *$ & 0.233 \\
\hline \multicolumn{5}{|l|}{ Slope $(\%)$} \\
\hline$<5$ & $1.012^{\mathrm{NS}}$ & 0.172 & $1.408 *$ & 0.151 \\
\hline $5-15$ & $0.646^{\mathrm{NS}}$ & 0.245 & $1.436^{*}$ & 0.170 \\
\hline $15-35$ & $0.982^{\mathrm{NS}}$ & 0.279 & $0.629^{\mathrm{NS}}$ & 0.276 \\
\hline$>35$ & $1.722 *$ & 0.242 & $0.098 * * *$ & 0.588 \\
\hline \multicolumn{5}{|l|}{ Aspect } \\
\hline None & $0.998^{\mathrm{NS}}$ & 0.170 & $1.329^{\mathrm{NS}}$ & 0.148 \\
\hline North & $1.950 * *$ & 0.222 & $0.229 * * *$ & 0.370 \\
\hline East & $0.858^{\mathrm{NS}}$ & 0.329 & $0.420 *$ & 0.356 \\
\hline South & $0.664^{\mathrm{NS}}$ & 0.313 & $2.101 * * *$ & 0.198 \\
\hline West & $0.643^{\mathrm{NS}}$ & 0.313 & $0.944^{\mathrm{NS}}$ & 0.231 \\
\hline \multicolumn{5}{|l|}{ RSG } \\
\hline LPx & $1.734 * *$ & 0.191 & $0.453 * * *$ & 0.143 \\
\hline LVx & $0.595 * *$ & 0.200 & $2.098 * * *$ & 0.145 \\
\hline AR & $0.524^{\mathrm{NS}}$ & 0.603 & $1.292^{\mathrm{NS}}$ & 0.363 \\
\hline $\mathrm{FV}$ & $0.708^{\mathrm{NS}}$ & 1.048 & $1.024^{\mathrm{NS}}$ & 0.555 \\
\hline LPst & $2.613^{\mathrm{NS}}$ & 1.158 & $14.761 *$ & 1.157 \\
\hline
\end{tabular}

Wald-test statistic:

$P$ values: $P<0.001-* * *$;

$P<0.01$-**; $P<0.05$-*

and ${ }^{\mathrm{NS}}$ not significant

forest expansion was predicted to occur 10-times more and almost 5-times more than in other areas, respectively. In contrast the probability of cork oak forest expansion occurrence in cork oak woodlands was somewhat inferior ( 0.8 times) to that in the other agroforestry systems.

Expansion of cork oak forests was more likely to occur in LPx, north aspect and steep slopes $(>35 \%)$ with odds ratio of 1.7, 2.0 and 1.7, respectively. The odd ratios found for sedimentary formations (LPst, AR, FV) were not significant. The cork oak forest expansion in LPx was almost 2-times more likely to occur than in other soils, whereas in LVx the expansion occurrence was about 0.4 that of the others.

Regression of cork oak forests was clearly more likely to occur in shrublands and agriculture lands (odds ratios of 7.0 and 4.7, respectively) while the probability of cork oak regression in woodlands was slightly inferior to that in the other vegetation classes (odds ratio of 0.9).

Almost 15-times more cork oak regression was predicted in LPst than in other areas. Higher regression was predicted for low slopes $(<15 \%)$ and for south aspect with odds ratio of 1.4 and 2.1, respectively, whereas lower regression was predicted with significant probability for steep slopes $(>35 \%)$ and for north and east aspects with odds ratio of 0.1 , 0.2 and 0.4 , respectively.

Two multivariate logistic regression models with all selected GIS variables were built using a forward stepwise method with a $\chi^{2}$ significant at $P<0.001$ $(10.932 * * *$ and $4.122 * * *)$ and with an overall accuracy of 89 and $84 \%$, respectively for the occurrence of expansion and regression of cork oak forests. However accuracy to predict areas of expansion or regression was very low (8.4 and $34.0 \%$, respectively) while it was high for predicting areas of no-expansion and no-regression (99.7 and 94.7\%, respectively).

The predicted probabilities for the occurrence of cork oak forest expansion and regression are in accordance with those obtained using the previous univariate logistic regression analysis. The maximum values of predicted probability for expansion were 
found in shrublands, in LPx with dominant north aspect, either in steep slopes, superior to $35 \%(0.65)$ and in slopes between 15 and $35 \%$ (0.58). For cork oak forest regression, the maximum predicted probabilities were found also in shrublands but in LPst, with dominant south aspect, in gentle undulating slopes between 5 and $15 \%(0.98)$ and in agriculture lands, in LPst, with dominant east aspect, also in gentle undulating slopes $(0.82)$.

The trends found for landscape features like soil, aspect and slope were similar in the three agroforestry systems: the LPx was the soil on schists formations with the highest predicted values for cork oak forest expansion and lower values for cork oak forest regression; the south dominant aspect showed the higher and lower predicted probability, respectively for cork oak regression and expansion; the higher slopes $(>35 \%)$ had the higher and lower predicted probability, respectively, for cork oak expansion and regression.

\section{Discussion}

Landscape dynamics

The county of S. Bartolomeu da Serra is a rural region where woodlands dominate and agriculture is present to a significant extent. In the 47-year study period (1958-2005), these characteristics were generally maintained, although land use changes occurred and impacted landscape structure and mosaic.

Land abandonment measured by the shift of agriculture and woodlands into shrublands was the key factor in the overall changes that occurred in S. Bartolomeu da Serra during the study period. This corresponds to the extensification trend in cork oak area land use, as defined by Barbero et al. (1990) and Pinto-Correia and Mascarenhas (1999), by which woodlands and agriculture lands are downgraded and eventually excluded from the production chain, with invasion by sclerophylous species better adapted to stronger soil and climate constrains. The shift of agriculture into woodlands could also be considered a sign of an extensification trend as it corresponds to a decreasing investment in agricultural activity.

The increase rate of shrublands is a high value when compared with the average rates for natural vegetation changes in the Mediterranean basin which has been reported to vary between 1 and 2\% (Barbero et al. 1990; Shoshany and Svoray 2002). Such a difference may be in relation with the impact of land use shift driven by abandonment.

Landscape fragmentation paralleled land-use changes and mean patch area of woodlands and agriculture lands decreased substantially in result of the scatter of shrublands within these areas, thereby increasing the mosaic diversity.

\section{Cork oak landscape dynamics}

The cork oak woodlands are dominant in the landscape of S. Bartolomeu da Serra. Their dynamics thereby coincide with the overall woodlands changes: the cork oak woodland area was stable over the 47-year period, in spite of the effects of land abandonment leading to transformation of cork oak woodlands into shrublands.

The main characteristics of the cork oak woodlands were maintained: dominance of dense stands with an herbaceous understory. The canopy cover dynamics corresponded to an overall increase of both dense and clear woodlands and in contrast, with a decrease in open woodlands. These main trends corresponded to the enhancement of the forest component of the agroforestry system, increasing the density in the existent cork oak woodlands areas and with new afforestation areas which were mainly located in agriculture areas. Somewhat different results were obtained by Carvalho et al. (1992) stating a decrease of dense stands for a similar region for the period 19581987, which can be explained because that period misses the cork oak afforestation EC programmes of the last two decades (1985-2005). Cano et al. (2003) report a loss rate of cork oak dense stands of $4.4 \%$ year $^{-1}$ for the period 1977-2000 in a "dehesa" in Cádiz, but there was no information on cork oak mortality and on how the new cork oak afforestation areas were accounted.

The incidence of cork oak mortality was lower in the stable agroforestry systems and higher in transition areas mainly when shrub encroachment occurred. This negative effect of shrub encroachment in the cork oak vegetation and especially of shrub encroachment dominated by Cistus ladanifer L. in schist areas, as it was observed in the study area, corroborates previous comments referring that the 
progressive disappearance of cultivation and grazing, accompanied by shrub encroachment, could lead to "montado" degradation (Barbero et al. 1990; Cabral et al. 1992). This is in line with the results showing that tree density in "montado" (and "dehesa") could be water-availability dependent (Joffre et al. 1999). The survival of trees relies on the extent of lateral and deep roots, and therefore on the competition between trees and understory and on the soil water content dynamics (Moreno et al. 2007; David et al. 2007). Moreover, these results could be enhanced by stress climatic conditions like increasing dryer year sequences (Fig. 1) as it occurred in the second half of the study period.

Cork oak area dynamics included two opposite transitions: forest expansion and regression with similar importance both on absolute areas as well as on their proportion of the cork oak area. However, expansion and regression differed strongly with the agroforestry system and, to a smaller extent, with landscape features.

Shrublands had the highest cork oak dynamics in relative terms both in expansion and regression of cork oak forests i.e., the highest values for EI and RI. This stresses the role of this vegetation class in the periods of disturbance and recovery of these ecosystems. The expansion of cork oak forests in shrublands may be explained by the protective role of shrubs in cork oak regeneration since cork oak is a species that needs shaded microsites (Torres et al. 1997; Serrasolses and Alloza 2004). However, a long-term absence of land-use and shrub overgrowth, in a scenario of increasing dryer years, may lead to significant increase in competition for soil water and nutrients between trees and shrubs (e.g., Genista hirsuta Vahl, Cistus sp. L., Lavandula stoechas L.) (Cubera et al. 2004; Montero et al. 2004; Cubera and Moreno 2007) and therefore to a potential cork oak decline. The balance may be fragile and sensitive to microsite conditions and to climatic factors, and could correspond to a definitive transition in landscape mosaic with consequences for the forest ecosystem restoration (Barbero et al. 1990; Pons and Pausas 2006). This was the case in S. Bartolomeu da Serra, where the net balance between expansion and regression of cork oaks in shrublands was clearly negative.

The analysis of cork oak forest dynamics in relation to soil types showed that it was in Leptosols developed on schists that cork oak forest expansion was highest and regression lowest. In spite of the reduced depth in these soils having been reported as the key factor regarding cork oak mortality (Diniz 1994), this did not seem to negatively influence the temporal dynamics of the cork oak forests. Schist fracturation and the location of this soil in the steep slopes with somewhat less constraints linked to cultivation may be contributing factors.

In contrast, the Haplic Leptosols developed on sandstones showed maximal RI. In this case the reduced soil depth affected the recovery of the cork oak system because it was located mainly in flat or gentle slopes where the anthropogenic disturbances are higher. The compacted parent material with significant clay content (Inverno et al. 1993) may also reduce the tree deep-rooting pattern (Fisher and Binkley, 2000) that could result in a higher dependence on the water and nutrients in the uppermost soil horizons in direct competition with the better-adapted understory (Barbero et al. 1990; Moreno et al. 2007). In Luvisols, the anthropogenic disturbances like grazing and livestock had a strong negative effect on cork oak recovery and the balance between expansion and regression of cork oak forest was negative. These findings show distortion of the human-maintained equilibrium considering the climatic stress and the edaphic constrains.

In relation to slope and aspect, the occurrence of new cork oak forests was higher in north aspect even in steep slopes, whereas regression was higher in gentle slopes with south or with no dominant aspect. This is in line with suggestions made by Cabral et al. (1992) and Sousa et al. (2000) who explained a higher cork oak decline in south aspect by an enhanced water stress caused by a more intense solar radiation.

\section{Prediction models}

The results obtained by the univariate logistic regressions were in line with the observations of expansion and regression of cork oak forests, namely regarding the determining role of the agroforestry system. Further, the logistic regression models for prediction of probabilities of expansion and regression of cork oak forests based on landscape attributes gave an insight on which type of areas would be more sensitive to shifting in S. Bartolomeu da Serra. 
However, the variables related to agroforestry system, soil type, slope and aspect were insufficient to predict accurately the occurrence of expansion and regression at a patch level and low match values for expansion/regression areas were found. These low match values shown by the models especially in woodlands could be related to the absence of tree related variables i.e., age, biometric features and cork exploitation intensity that can be also factors inducing cork oak mortality (Cabral et al. 1992; Cadima et al. 1995), as well as of microsite climatic conditions, namely regarding water availability.

\section{Conclusions}

Cork oak woodlands were particularly stable during this nearly 50-year period regarding both total area as well as the dynamics of expansion and regression of the cork oak forests. This is indicative of the basic sustainability of the "montado" system in the study area, albeit it has been considered as an endangered region regarding cork oak decline. However, long term sustainability has to cope with the intensity of land use change and with shifting of the agroforestry system, a process that is mainly driven from socioeconomic factors, leading to agriculture and overall rural abandonment. These were the key factors for cork oak dynamics.

The results obtained can be used as a tool to plan mitigation actions against cork oak forest regression and for promoting the sustainability of the cork oak "montado". On one side, the importance of shrublands was recognized as potential regeneration areas for cork oaks if they are controlled to prevent overgrowth, thereby calling for the need of shrub management. On the other side, access to water resources and relationship to soil-site conditions are key factors for cork oak development especially when considering future increasing drought scenarios.

Acknowledgments The first author thanks Fundação para a Ciência e a Tecnologia (Portugal) for a scholarship under the POCI 2010 Programme. Cooperation of Direcção Geral dos Recursos Florestais and of Núcleo Florestal do Alentejo Litoral (Portugal) is acknowledged. The authors thank the cooperation of Prof. Nuno Cortez regarding soil classification. The authors acknowledge the comments of one anonymous reviewer.

\section{References}

Barbero M, Bonin G, Loisel R et al (1990) Changes and disturbances of forest ecosystems caused by human activities in the western part of Mediterranean basin. Vegetatio 87:151-173. doi:10.1007/BF00042952

Brasier CM (1996) Phytophthora cinnamomi and oak decline in southern Europe. Environmental constraints including climate change. Ann For Sci 53:347-358. doi:10.1051/ forest: 19960217

Brasier CM, Scott JC (1994) European oak declines and global warming: a theoretical assessment with special reference to the activity of Phytophthora cinnamomi. EPPO Bull 24(1):221-232. doi:10.1111/j.1365-2338.1994.tb01063.x

Cabral MT, Ferreira MC, Moreira T et al (1992) Diagnóstico das causas da anormal mortalidade dos sobreiros a Sul do Tejo. Scientia gerundensis 18:205-214

Cadima ISP, Capelo J, Gomes AA (1995) Relação entre variáveis ambientais, tipos de condução dos povoamentos e a mortalidade do sobreiro nos concelhos de Sines, Grândola e Santiago do Cacém. Silva Lusitana 3(1):85-107

Cano F, Navarro RM, Ferrer AG (2003) Evolución de la cubierta de alcornoque en un monte afectado por la seca (La Alcaidesa-Cádiz) mediante una secuencia de fotografías aéreas. Ecologia 17:131-144

Cardoso JVC (1965) Os solos de Portugal. Sua classificação, caracterização e génese. 1-A Sul do rio Tejo. D.G.S. A. Lisboa

Carvalho EC, Mascarenhas JM, Silva IC et al (1992) Análise diacrónica por fotointerpretação dos montados de Quercus suber L. da região de Santiago do Cacém, Grândola e Sines. In: $2^{\circ}$ Encontro dos Montados de Sobro e Azinho, Évora, pp 288-300

Costa JC, Aguiar C, Capelo JH et al (1998) Biogeografia de Portugal Continental. Quercetea 0:3-56

Costa A, Madeira M, Oliveira AC (2008) The relationship between cork oak growth patterns and soil, slope and drainage in a cork oak woodland in Southern Portugal. For Ecol Manage 255:1525-1535

Cubera E, Moreno G (2007) Effect of land use on soil water dynamic in dehesas of Central-Western Spain. Catena 71(2): 298-308. doi:10.1016/j.catena.2007.01.005

Cubera E, Montero MJ, Moreno G (2004) Effect of land use on soil water dynamics in dehesas of Central-Western Spain. In: Schnabel S and Ferreira A (eds) Sustainability of agrosilvopastoral systems - dehesas, montados. pp 109-123

David TS, Cabral MT, Sardinha RMA (1992) A mortalidade dos sobreiros e a seca. Finisterra XXVII:17-24

David TS, Ferreira MI, Cohen S et al (2004) Constrains on transpiration from an evergreen oak tree in southern Portugal. Agric For Meteorol 122:193-205. doi:10.1016/j.agrformet. 2003.09.014

David TS, Henriques MO, Kurz-Besson C et al (2007) Water-use strategies in two co-occurring Mediterranean evergreen oaks: surviving the summer drought. Tree Physiol 27: 793-803

DGF (1985) Distribuição da floresta em Portugal Continental (Áreas florestais por concelhos). Estudos e informação 297 
DGF (2001) Inventário Florestal Nacional, Portugal Continental-3 $3^{\mathrm{a}}$ Revisão 1995-1998. Direcção Geral das Florestas, Lisboa

DGRF (2007) Resultados do Inventário Florestal Nacional 2005/06. Inventário Florestal Nacional. Direcção-Geral dos Recursos Florestais, Lisboa

Diniz AC (1994) Os solos do montado e aptidão suberícola nos concelhos de Grândola, Santiago do Cacém e Sines. Correlações com a morte prematura do sobreiro. Silva Lusitana 2(2):247-267

Fisher FR, Binkley D (2000) Ecology and management of forest soils, 3rd edn. Wiley, United States of America

Gouveia AC, Freitas H (2008) Intraspecific competition and water use efficiency in Quercus suber: evidence of an optimum tree density? Trees Struct Funct 22(4):521-530. doi:10.1007/s00468-008-0212-0

Inverno CMC, Manuppella G, Zbyszewski G et al (1993) Carta Geológica de Portugal na escala 1: 50000-42C. Notícia explicativa da Folha 42 C Santiago do Cacém. Serviços Geológicos de Portugal, Lisboa

Joffre R, Rambal S, Ratte JP (1999) The dehesa system of southern Spain and Portugal as a natural ecosystem mimic. Agrofor Syst 45:57-79. doi:10.1023/A:1006259 402496

Miranda P, Coelho FES, Tomé AR, Valente MA (2002) 20th Century Portuguese climate and climate scenarios. In: Santos FD, Forbes K, Moniz R et al (eds) Climate change in Portugal. Scenarios, impacts and adaptation measuresSIAM Project. Gradiva Publishers, Lisbon, pp 23-83

Moniz M, Tomaz I, Cabral M et al (1996) Avaliação da patogenicidade de Phyphtora cinnamomi Rands em sobreiro (Quercus suber L.). Silva Lusitana 4:79-88

Montero MJ, Obrador JJ, Cubera E et al (2004) The role of dehesa land use on tree water status in Central-Western Spain. In: Schnabel S, Ferreira A (eds) Sustainability of agrosilvopastoral systems - dehesas, montados, pp 125-136

Moreno MG, Obrador JJ, Gárcia E et al (2007) Driving competitive and facilitative interactions in oak dehesas through management practices. Agrofor Syst 70(1):25-40. doi:10.1007/s10457-007-9036-y

Nogueira S (1990) Floresta Portuguesa. DGF Informacao 2:18-28

Oak S, Tainter F, Williams J et al (1996) Oak decline risk rating for the southeastern United States. Ann For Sci 53: 721-730. doi:10.1051/forest: 19960248

Oliveira G, Correia OA, Marins-Loução MA et al (1992) Water relations of cork oak (Quercus suber L.) under natural conditions. Vegetatio 99-100:199-208. doi:10.1007/BF00118 226

Oszako T (2000) Oak declines in Europe's forest-history, causes and hypothesis. In: Oszako T, Delatour C (eds) Recent advances on oak heath in Europe. Forest Research Institute, Warsaw, Poland, pp 11-40

Pereira H (2007) Cork: biology, production and uses. Elsevier, Amsterdam

Pereira PM, Fonseca MP (2003) Nature vs nurture: the making of the montado ecosystem. Conserv Ecol 7(3):7-37
Pereira C, Santos M (2003) Áreas queimadas e risco de incêndio em Portugal. DGF, Lisboa

Pereira H, Tomé M (2004) Non-wood products: cork oak. In: Burley J, Evans J, Youngquist JA (eds) Encyclopedia of forest sciences. Elsevier, Oxford

Pinto-Correia T, Mascarenhas J (1999) Contribution to the extensification/intensification debate: new trends in the Portuguese montado. Landsc Urban Plan 46:125-131. doi: 10.1016/S0169-2046(99)00036-5

Pinto-Correia T, Vos W (2004) Multifunctionality in Mediterranean landscapes-past and future. In: Jongman R (ed) The new dimensions of the European landscape. Wageningen UR Frontis Series No. 4. Springer, Germany, pp 135-164

Plieninger T (2006) Habitat loss, fragmentation and alterationQuantifying the impact of land use changes on a Spanish dehesa landscape by the use of aerial photographs and GIS. Landscape Ecol 21:91-105. doi:10.1007/s10980005-8294-1

Pons J, Pausas JG (2006) Oak regeneration in heterogeneous landscapes: the case of fragmented Quercus suber forests in the eastern Iberian Peninsula. For Ecol Manage 231: 196-204. doi:10.1016/j.foreco.2006.05.049

Serrasolses I, Alloza JA (2004) Condicionantes edáficos en la restauración forestal mediterránea. In: Vallejo VR, Alloza JA (eds) Avances en el studio de la gestión del monte mediterráneo. Fundación CEAM, Valencia, pp 133-160

Shifley SR, Fan Z, Kabrik JM et al (2006) Oak mortality risk factors and mortality estimation. For Ecol Manage 229: 16-26. doi:10.1016/j.foreco.2006.03.033

Shoshany M, Svoray T (2002) Multidate adaptive unimixing and its application to analysis of ecosystem transitions along climate gradient. Remote Sens Environ 82:5-20. doi:10.1016/S0034-4257(01)00346-7

Sousa E, Pinto J, Santos M et al (2000) Association of soil macro and microelements and cork oak decline in Portugal. In: Oszako T, Delatour C (eds) Recent advances on oak heath in Europe. Forest Research Institute, Warsaw, Poland, pp 215-218

SPSS (2008) SPSS 15.0 vs for Windows. SPSS Inc., Chicago

SROA (1962) Carta de Solos de Portugal na escala 1:50,000. Folha 42C. Serviço de Reconhecimento e Ordenamento Agrário. Secretaria de Estado da Agricultura, Ministério da Economia, Lisboa

Torres EA, Montero GG, Suárez de la Cámara MA (1997) Seguimiento de la regeneración natural de alcornoque bajo condiciones microecológicas diferentes. In: I Congresso Hispano Luso II Congresso Forestal Español, Panplona, pp 535-540

Wargo PM (1996) Consequences of environmental stress on oak: predisposition to pathogens. Ann For Sci 53:359-368. doi: 10.1051/forest: 19960218

WRB (2006) World reference base for soil resources. A framework for international classification, correlation and communication. World Soil Reports 103, 2nd edn. FAO, Rome 